\title{
A World Community of Old Trees: An Ecology Art Project on the World Wide Web http://www.nyu.edu/projects/julian/
}

\section{June Julian}

\section{Background}

The research project, "A World Community of Old Trees," has its beginnings with real students with deep concerns. To give life to the black marks of text below, imagine young people in grades 7-12, worrying out loud in the art room over the years, about the environment, and about what they could possibly do to help. Please hear their voices as the inspiration behind the research. This project is for them.

Although the conducting of an ecology art project on the Internet has several on-line precursors, all of the early projects that I could find were exclusively text-based (Julian, 1994). Background research shows that "A World Community of Old Trees" is a pioneer ecology-based art education research project on the World Wide Web. Because of the graphics nature of the Web, participants and viewers can watch the project unfold over time as it develops on-line.

Earlier ecology art projects provided project instructions via e-mail and exchanged student art work at the conclusion of the project via regular mail. With the World Wide Web, student art work and text can be placed in an on-line Gallery as it comes in. This capability for interactive graphics and text developing over time on-line is what makes "A World Community of Old Trees" a unique forum for

"A World Community of Old Trees" is the research component of the Ed.D. dissertation in progress titled: Art Education On-Line: Toward a Theory of Ecology-Based Art Education. The philosophical bases for the study are the ecology philosophy of Aldo Leopold and the environmental aesthetics of Amold Berleant. With a grounding in the work of both of these thinkers, the research project calls for deep personal involvement with nature.

Leopold wrote "That land is a community is the basic concept of ecology" (Leopold, 1949, p.viii). An Ecology-Based Art Education necessitates art teaching that embodies the idea of community, the community of all living species in the largest sense, and a community of learners within a specific project.

Environmental aesthetics as described by Arnold Berleant calls for deep personal engagement with the physical world, a "true synaesthesia, a complete union of the sensory modalities" (Berleant, 1992, p. 28).

Berleant, like Leopold, stresses the interconnectedness of all living things and calls for vivid description of experiences with nature. His works 
provide an appropriate model for ecology art projects, where students are encouraged to describe their world acutely and personally, as part of a community.

The practice of Ecology Art in the contemporary art world is a phenomenon that probably had its first incarnations in the 1970's with the art work of Newton and Helen Mayer Harrison. This couple focuses on an ecological problem somewhere in the world and through elaborate maps, charts. poetic texts and photographs, shows their design for a solution. (Cembalest, 1991, p.98). Current Ecology Art, a particular sensibility to making art about our interrelationship to our physical world, is a wide open category. Artists from all over the world are making art about everything from garbage to electromagnetic radiation, and of course, trees.

The promoting of environmental issues through art is not really new. From Paleolithic times to the present, human beings have been trying to make sense of their relationship to nature through art. Ecology-Based Art Education on-line, not only participates in this long tradition, but extends it beyond the self, beyond a single culture, exponentially, through the computer.

\section{Statement of the Problem}

By conducting "A World Community of Old Trees" on the World Wide Web, my purpose is to examine the potential of the Web as an interactive medium for communication and exchange for an ecology art project.

At the time of this writing, the project is engaging students, teachers, and artists, from around the world in identifying, writing about, and documenting with original visual art, the oldest trees in their environment. So far, student participation has come from various parts of the United States, including Ohio, Texas, Nevada, New York, New Jersey, Massachusetts, and from several foreign countries: Lithuania, Belarus, Mexico, and Australia, with more coming in every day.

Since the project's Web site has three main components, the Tree Gallery, the Tree Museum, and Tree Talk, there is ample and diverse digital space for participants to showcase art work as well as to contribute text

The Tree Gallery, itself, has two main sections: one for student projects and the other for the imagery sent in from contemporary artists. The Gallery may include internal links, i.e., links to other "pages" on the project's Web site, or external links, i.e., links to other relevant Web sites.

The Tree Museum invites participants to contribute either text or imagery to three sections: (a) the An notated Bibliography, where participants can point to tree information or tree imagery in standard print media, (b) Web Sources, which contains URL's (Web addresses) for sites relevant to the project, and the (c) Image Bank, where there are uncopyrighted images of existing trees that may be used as bases for art work. 
The Tree Talk component of the project provides a space to share information and to discover ecological facts about ancient trees with internal and external links. It also includes a Commentree section where participants and Web surfers can share their comments and engage in an open discussion about the project.

At the conclusion of the student project component of the research project, selected ecological and post-modern education criteria such as openness, interrelatedness, and interactivity will be used to examine the results. Then, recommendations will be made to classroom art teachers for the use of the World Wide Web for ecology art projects.

"There is no all encompassing post-modern model; in fact, such a concept violates the openness of post-modernism's emphasis on each practitioner being a curriculum creator and developer, not just an implementor" (Doll, 1993, p16).

\section{Method}

The research has three distinct phases: (a) What was the case and What is the case? (b) What could be the case? and(c) What should be the case? (Ecker, 1992). Each phase employs one of three successive levels of discourse in Aesthetic Inquiry as outlined by Ecker and Kaelin (Ecker \& Kaelin, 1972). For example, for the first phase, the inquiry was at the critical level where computer data on past and present Ecology Art Projects was collected from sources on the Internet to determine the history and status of similar projects. For the new Internet Ecology Art Project in phase two, the method of research is operating at the meta-critical level, addressing the findings of phase one and conducting the new Internet Ecology Art Project on the World Wide Web. The new project is, in fact, the metacritique in process. Finally, the third phase, at the theoretical level, will examine the completed project and make curricular recommendations.

"A World Community of Old Trees" addresses the question, What could be the case? Here a global community of learners is engaged in an open system of art production, dialogue, and criticism. The call for participation for this on-line project was posted on various educational listservs and Web sites, specifying exclusive participation for art teachers and their students in grades $\mathrm{K}-12$.

The Shared Guidelines for the project are an application of Ecker's Criteria, Concepts, and Activities model (Ecker, 1992):

r.riterion: Ecological issues should be inteyrated into art education Concept: The Internet provides a way to practice ecology art principles

Activity: Students find the oldest and biggest trees in their community; write descriptive text including the correct common and Latin name for the species, its location, estimated age, 
circumference (54 inches from the base), local history, and personal reactions; document the tree with sketches and photos; and produce a final image of the tree in any medium.

Participants are instructed to send their art work to the researcher's e-mail account either as an e-mail attachment as a gif file not to exceed $50 \mathrm{~K}$, or to send their materials via snail (regular) mail.

As I receive each participant's work, I write an HTML (hypertext mark up language) document to include the student's name and school, their picture file, their descriptive text, and their tree size and identification information. Then I transfer this file to the server and their contribution becomes live on the Web for all to share.

The idea has always been to encourage an open, democratic, and multicultural community of leamers. Everyone will have access to all imagery on the site. Responses are invited about the project as it unfolds and at the close.

For the final question, What should be the case? , at the end of the Student Projects component, I will evaluate the potential of the World Wide Web as an interactive system for the conducting of an ecology art project. The on-line research itself should suggest ways to accomplish this evaluation. Some possible ways might be to request participants' self-evaluation, and to put out an open call for the project's evaluation on various educational listservs and Web sites. In this way, the evaluation criteria would come from without, rather than be imposed from within. A final assessment might be combined with my own observations of the presence of the beginning criteria of openness, interactivity, interrelatedness, community, etc. Since the dialogic process of the project itself could suggest other categories for analyses, this list then, is also open. Theory building comes from the combined observations of the researcher and the participants. In this way, the project 's entire on-line community produces responses to the question. What should be the case?

\section{References}

Berleant, Arnold. (1992). The Aesthetics of Environment. Philadelphia: Temple University Press.

Cembalest, Robin. (1991). The Ecological Art Explosion. Art News 90 (6), 96-105.

Doll, William E. (1993). A Post-Modern Perspective on Curriculum. New York: Teachers College Press.

Ecker, David W. (1992, January). Projects for Cooperative Research and Development in Arts Education, Third Annual South Carolina Higher Education Forum. Columbia: University of South Carolina.

Marilyn Zurmuehlen's Working Papers In Art Education 1996-1997 
Ecker, David W. \& Kaelin, Eugene. (1972). The Limits of Aesthetic Inquiry: A Guide to Educational Research. Philosophic Redirection of Educational Research. 258-286.

Julian, June. (1994). Art Education On-Line: Toward a Theory of Ecology-Based Art Education. In C. Marshall (Ed.) Aesthetic Investigations, New York: New York University, Department of Art and Arts Professions, 38-43.

Leopold, Aldo. (1949). A Sand County Almanac. New York: Oxford University Press. 